\title{
Ways to Defend Citizenship Rights in Civil Law of the Islamic Republic of Iran and Republic of Tajikistan
}

\author{
Abdolhossin Hasani ${ }^{1}$ \\ ${ }^{1}$ International University of Fundamental Studies, Iran \\ Correspondence: Abdolhossin Hasani, International University of Fundamental Studies, Iran.
}

Received: September 4, 2016

doi:10.5539/jpl.v10n1p234
Accepted: October 2, 2016 Online Published: December 29, 2016

URL: http://dx.doi.org/10.5539/jpl.v10n1p234

\begin{abstract}
Given enforceable rules and regulations that govern the relations of individuals in society, two kinds of rights can be derived: private and public. When we speak about the citizen and his/her rights, we mean a set of private and public law that governs social relationships. In fact, expression of citizenship rights means that every person enjoys as being a citizen of a country. The importance of the citizenship rights is to the extent that is closely related to place the rule of finds and even some experts believe that a society in which the rights of citizens and the relationship between people and government falters cannot be established. Guarantee of the fundamental rights of citizens, primarily implies by inserting these rights in the constitution of every country act. In other words, it takes an effective step in the process of constitution rule of law, freedom and enjoyment of facilities and take citizenship. But we must consider the fact that the protection and safeguarding of the rights of individual citizens is on the shoulders of all powers and government agencies that have the necessary measures to protect the rights of citizens. Besides, their executive units operate in all administrative formalities the rights of citizens and legal and in the case of not conforming citizens' rights are not overwhelm the device government should have a competent judicial authorities that the rights of individuals against the government defend the principles of a fair trial. So the fundamental rights of citizens included in the constitution and other laws, required to comply with these rights by the state, there is a competent judicial body that complaints about violation of their people by governmental agencies and monitor governmental bodies are responsible in this regard. All of them are standards implementation and guarantee of the rights of citizenship in a democratic society. Comparative analysis of compliance standards in the legal system of Iran and Tajikistan is a major point of discussion at the end, to recognizing the strengths and weaknesses of both countries and richer the implementation and monitoring of the implementation of the rights to use the experiences of the countries.
\end{abstract}

Keywords: citizenship and civil rights, civil rights and modern elements, monitoring devices of the proper implementation of civil rights, Iran rights, Tajikistan rights

\section{Introduction}

Citizenship as it is clear, is a from city derivatives. They know citizenship as an advanced form of "urbanization". According to some experts, the urban when we respect each other's rights and their responsibilities towards the city and the community to act as 'citizen' have been upgraded. Citizenship is already checked in urban areas, but then its notions of citizenship are extended to state and country, although today many may think to "global citizenship". Nowadays citizenship has found different meanings.

At the core of citizenship, the subject is always belongs to a society that plays the policies and actions. Citizenship always has a political dimension, because citizens have the ability and capacity legislation. Citizens belong to communities and are defined as groups of people accept that things have in common. What unites them is possible simply accepting the legitimacy of governments that live within a common element may be an effective and strong solidarity based on shared history, ethnicity, religion or common purpose (Hemmati, 2008).

A citizen is a member of a city, state or country. This view reminders rights and responsibilities to citizens that have been developed in law. In this urban vision of citizenship rights, relations between the people of the city, their rights and duties towards each other and the principles and goals and tasks and way of doing it. In fact, civil rights are a mix of duties and responsibilities of citizens for each other, city and state or country's ruling forces and the laws and the duty to ensure that the rights privileges of city managers (municipalities), general government or the ruling powers. The set of rights and responsibilities refers to "civil rights" (Sugar, 2007). 
Basically, in any democratic society respect peoples' rights in this regard seems essential, in addition to codifying the rules of order in any society is the rights and duties of citizens and governmental bodies also express the device and organizations in charge of enforcing the law should respect the law of his duties better citizens of their rights. But in all democratic societies, governmental agencies and the oversight of the executive branch because of the substantial powers are minimal, as one of the most important principles is to uphold the rights of citizens. Monitoring of political power in the history of political thought in the field of supervision, internal and external monitoring has been studied for the prevention of corruption in the government and ruling monitoring actually carried out and one of the very important aspects to achieve this, but in the communities and limiting the trappings of a variety of situations is raging that is different (Muharram, 2005).

Control of state machines can be divided into three administrative oversights, parliamentary oversights and judicial oversight. In the administrative supervision of the monitoring is done by the executive branch, such as the possibility of impartial administration in dealing with administrative claims this method has not been confirmed. In this method parliamentary oversight is important, but it is more useful for assessing the progress of objectives and plans. This method of monitoring the judiciary, the administration of justice for the rights of the citizens' wireless device there is a special place (Tabatabai Motameni, 2008).

Judicial supervision has been used in three seemingly different concepts, but they all share a common goal:

1) The Supreme Court judicial supervision of the Court in the judicial hierarchy.

2) The Court judicial supervision of constitution or similar political institutions on compliance with the constitution, laws and Acts of Parliament that monitors the constitution or "fundamental justice" is interpreted.

3) Judicial supervision of the courts, including administrative courts or general courts on the legality of government actions and decisions that interpreted to judicial review (Hadavand, 2008).

In this paper, we try to have a comparative study of citizenship and its elements as well as log monitoring the proper implementation of civil rights organizations in Iran and Tajikistan to be addressed.

\section{The Relationship between the Citizen Rights and Some Legal Concepts}

\subsection{Globalization and Citizenship}

In recent years the debate about globalization has a significant importance in various circles. First and foremost, this importance comes from breathtaking acceleration and the intensity of the globalization process. The phenomenon with a huge impact any try and rush, scientific, theoretical and application-to-understand explanations makes it justified and necessary (Rose, 2002).

Two broad implications for global governance discourse: Firstly, political, social and economic global scope and cause of the disappearance of the distinction between sovereignty and legal equality of states in foreign level. So the relevance of the rule doesn't have a subject. In this sense, globalization is nothing more than the decline of autonomy refers to the globalization of our view of the changing political landscape shifted and the political procedure necessary adjustments. Because the distinction between the internal governance and the equality of international according to Richard Cooper is no longer useful because foreign policy is domestic politics and foreign policy, domestic policy (McWilliams, 2000).

Globalization is a term often used to describe the flow below:

A - The rapid spread of new information technologies to the communications revolution, led production and trade to facilitate the dissemination of cultural values have been on the international level.

B - The emergence of a global economy based on activity-based transnational companies and international markets for capital, goods, services and opportunities.

$\mathrm{C}$ - The formation of regional markets and economies based on features free movement of capital, goods and labor along state borders - National "Union of Europe" the most advanced example of this is going on, but "North American Free Trade Area" (NAFTA) and the "Asian Cooperation - Pacific "(APEC, free movement in some areas only allow, but not in all areas.

D - development of supranational institutions and legal norms to regulate the economic and political relations (including Europe, the World Court, the European Court of Justice, the WTO, etc.)

E - The growing importance of democracy and human rights as universal norms to govern the global community fairly.

F - Creating a global commitment to a common set of values and standards of monitoring the "no" as a result of the transformation of information and cross-cultural awareness. 


\subsection{The Impact of Globalization on Citizenship}

Globalization, Citizenship and influenced in many ways, this effect is notable that two of its three sides, indirect and background, but is more a place for it. The first is that the globalization concept of "relative autonomy" of the state - National Citizenship separate nation that has been based on it, the following question. Globalization, the land, the point of connection between power and discrete location and Yuyurka about his attention turned to the collapse of the national industrial societies. National industrial society course of its development in the nineteenth and twentieth centuries, three of the community, state and nation specially linked to each other.

The second aspect of the impact of globalization is weakening the ideological support of national culture distinct and relatively independent. National distinct culture has always been a myth, because almost all governments Nations of ethnic groups with different languages, different traditions and histories are made. That is why the assimilation placed at the head of the nationalist project. "Others" which were within the territory of the nation-state, before they become citizens should become a national citizen (Davidson and Castells, 2003).

The third aspect of globalization's impact is synergistic aspects of migration. Globalization in this sense, involves the movement of people across national boundaries is increasing. The period after 1945 and especially after 1980, witnessed massive immigration - of all kinds - Respectively. The characteristics of this period of transition, temporary and permanent labor migration and mass exodus of refugees, family and personal travel and migration, technical professionals, skilled and unskilled workers respectively. The result of this migration, mainly accommodation most developed countries and in many sectors and regions has been less developed. As a result of this migration, the population of the more gross and cultural diversity have also suffered. Cultural differences and social marginalization, often interconnected have led to the formation of relatively unfavorable position and are isolated from the community for ethnic minorities. Aside from long-term migration, displacement also includes other forms that may have a significant impact on the local economy and culture. This handling forms of tourism, travel and the movement of short-term experts and business executives to educate and train young people to be (Ibid).

\section{Human Rights and Citizenship}

\subsection{The Concept of Human Rights}

Human rights are inalienable fundamental rights which are deemed essential for human life.

The Universal Declaration of Human Rights, dated December 10, 1948 referring to the "equal and inalienable", "all members of the human family" and "conscience of humanity" universality of human rights is emphasized. This universality shows in the Declaration of Rights 1948 Human quite visible. Where the word "global" was used instead of "international". So we can say that ensuring the universality of human rights is one of the main ideas of the Declaration is based and the recognition of the universality of determination in pursuing one of the goals of this declaration (Gross Alpyl, 2003).

In any case, the legal writings of contemporary human rights are increasingly divided into three separate categories:

The first generation of rights: civil and political rights

The second generation rights: economic, social and cultural

Third generation rights: collective rights

Now human rights are one of the most important issues in contemporary international law, there is respect and sensitivity towards universal numerous documents on the rights codified tried, in many countries, institutions and the Committee to follow up the issue intended or even a ministry has been established as human rights. And finally, the United Nations Secretary-General Kofi Annan's continuing efforts to create a Human rights Council as one of the pillars of the United Nations is a council which is to be in a position aligned with the executive powers of the UN Security Council and wider than its predecessor (Human rights Commission) is one of two main levers implement the decisions of the United Nations.

\subsection{Respect for Human Rights and Civil Rights}

If human rights represent the most common will of the members present in developed societies recognize and respect the decisive factor in determining the rules of social behavior and community values product, the basic terms of the obvious differences in the values, the garlic evolution of human societies in general will lead to the adoption of a rule of conduct with regard to the effects on each of these disparate communities of various factors including geographical, economic and ultimately political and cultural study. Only the approach this kind due to the Universal Declaration of Human rights can be in the process of evolutionary development of Western 
civilization achieved. That is, by exploring why this is achieved with such attitude can be both philosophically and historically against the principle of the Universal Declaration Human rights should be the continuation of social evolution at a point in history to issue the Magna Carta (1215 AD) in the United Kingdom, the Declaration of the rights of man and citizen (1789) in France, the Bill of rights (1791 AD) America, and the Universal Declaration of Human rights (1948) and led by the United Nations General Assembly today universality of human rights.

\section{Government and Citizens}

\subsection{The Concept of Government}

The government refers to the political status of people who are enclosed in a territorial unit organized (Hemmati, 2008).

Among the responsibilities of the state, pay the taxes and tolls by the public sector to provide the following services to citizens:

- Protection of life and property and the rights and security of citizens: police, fire, rescue in the event of unforeseen services, the courts and the judicial system and the armed forces.

- Health: water and healthy food, milk and meat inspection, maintenance of hospitals.

- Education: school and public libraries.

- Maintenance, repair and construction of roads, highways, streets and railways.

- Conservation and protection of natural resources, forests and the environment.

- Protection of savings, with inspection of banks and guarantee bank accounts.

- Assistance and compensation in cases of unforeseen such as floods, earthquakes and droughts (Schmitt, 2008).

\section{Develop the Concept of Citizenship in Iran}

\subsection{The History of the Development of the Concept of Citizenship in Iran}

Although issues such as citizenship, culture, citizenship and civil rights in the legal literature, politics and sociology of words that are new, but the concept is quite well-known. A citizen who is under the authority and backed by a government, have a set of basic human rights. Today, it is believed that people thought and as a citizen, as well as the rights and freedoms that the government is obliged to support them, assignments and responsibilities are also responsible for them. To develop a culture of citizenship and representation, guarantee and protect the rights of citizenship, civil rights in the context of society and the laws must be identified.

All citizens were not known in ancient Persia at that time social benefits were determined on the basis of the four divisions of class and hence justice, equality and universal rights concepts are unknown in that era did oppression astroploatation discrimination and commonplace among the upper classes with the majority of people who were on the fourth floor was the ordinary people of the lower class is that when you pay your taxes, and taxes are the kings of their land as military force in the military, or in general, matters were made public citizen was a strange word for ordinary people in those days and their vassal kings were known to a citizen (Amid Zanjani, 2006).

After the advent of Islam in Iran over the past military to respect human rights and was founded based on equality and human rights. In this system, the gap was banned any virtue and superiority of human beings them. So everyone, whether Islamic law dries rights of men and women, young and old is the same.

As for the governments that emerged after the advent of Islam in Iran in the Safavid rulers to respect citizens' rights we are witnessing. Authority Chairman Duty to protect citizens from abuses of their governments and advocate of human rights abuses against government officials. But under the law for citizens' rights are still not registered. During the reign of the Qajar we see as the biggest event in the history of Iran's constitutional revolution and the passage of the constitution as the constitution of Iran's constitutional revolution at Persian date 8th Dey 1285 solar (14th Zyqadeh 1324 moon) was signed by Muzaffar al-Din Shah until 1978 that vanished constitutional government in Iran, Iran's constitution. The constitutional amendment from the eighth to the twenty-fifth chapter entitled to bring people's rights. So for the first time citizens have rights and rather than as subjects, people went about their work.

But as it turns out the Iranian Constitutional constitution was not enforced in practice and in his life, nearly one hundred years of despotic and reactionary forces raped repeatedly. 
With the Pahlavi regime once again urged people were suppressed and people of the Islamic Republic of Iran in 1357 as their favorite government accepted the revolution. The Iranian constitution the rights of citizens in an integrated manner the rights of the people mentioned.

\subsection{Citizens in the Legal System of the Islamic Republic of Iran}

\subsubsection{Citizens Believed in Twelver Shi'a Faith}

The Islamic Republic is considered a religious state and all its laws based on Islamic law are dumped. Iran's constitution in Article XII official religion of Iran and the official religion of Islam and the Twelver Ja'fari and the principle forever unchanging knows. So, according to this principle that citizens are Shiai have priority while other citizens who believe in other religions as well as non-Muslim citizens provisions is as follows:

\subsubsection{Citizens Who Believe in the Other Islamic Faiths}

Hanafi, Shafi'i, Maliki, Hanbali blew the citizens are accorded full respect and followers of these religions are free to practice their religious and personal affairs and religious education and lawsuits related to them in court and in any area of law. The followers of these religions constitute the majority of local regulations in the jurisdiction of the council under the protection of the rights of the followers of other religions would be religions. ${ }^{1}$

\subsubsection{Citizens Who Believe in Other Religions}

Iranian citizens Zoroastrianism, Judaism only recognized religious minorities are free to practice their faith within the law and in matters of personal affairs and religious education act according to their faith. 2

\subsubsection{Other Citizens}

The government and Muslims are obliged to treat non-Muslims in conformity with ethical norms and Islamic justice and respect their human rights. It runs about those who do not use conspiracy against Islam and the Islamic Republic.

Human can be seen in the other religions constitution for citizens to enjoy their conditions of its citizens' rights and interfaith about other people who do not believe in this more rigorous enforcement. Of course, this premise that access to public office and employment is somewhat stricter. The two conditions jobs belief in Islam and the beliefs of the Islamic Republic filed in the Supreme Leader can be seen in most employment law can be said to be a condition of equality in access to public service in some neglected.

\subsubsection{Citizens of Women in Iran}

Iran's constitution in the twentieth everyone, both men and women in the law and enjoy all human, political, economic, social and cultural norms of Islam knows the same. In the twenty-first state constitution requires that women's rights in all respects in conformity with Islam guarantee.

But in practice these rights were not respected well with the word "men" in Article 115 and ambiguity in the term women are denied access to the official practice. Similarly, the arrival of the army, women can only medical and nursing professions are working in the army. But even where the law if it is not based on the lack of women entering the arena, women are not actually entering these areas, for example, a member of the Guardian Council and the Expediency Council membership.

So to the conclusion that in addition to the law in some cases prohibit women from participating in political culture, political socialization in other cases because of the weakness in the employment of women, this stratum of society from entering into politics, and this may be partly excluded as "second class citizens" about women being admitted.

\section{The Legal Status of Citizens' Political Rights in the Iranian Legal System}

\subsection{Political Participation}

As the company's political participation in political activities people participate in decisions affecting their status and if this refers to the process of democratization as an implicit policy to get, and it is particularly participating politically, citizens organized effort to select their leaders and political influence in this way means that guidance. In other words, the notion of political participation involves sharing socially active and non-top-down mass against individuals and groups (especially poor people and groups) in an effort order to guide the destiny and the improvement of their lives, using the organization terms involvement in decision-making and increased control

\footnotetext{
${ }^{1}$ Article XIII constitution of the Islamic Republic of Iran

${ }^{2}$ Article XIV constitution
} 
over political institutions.

Michael Rush knows, engaging in political activities at different levels of the lack of political participation, political involvement and public officials (Rush, 1998). Anthony Giddens political participation as a political right under consideration and the definition of political have a certain rights such as the right to vote in local elections and national rights to participate writes that citizens and communities (Shahbazi, 2001).

It's important to note that to achieve real political participation in the political institutions of society should participate in the community to come so we can say participation of institutions on the principle of political participation and priority is dedicated. Because of the dispute, the legitimacy of the political system and level of political participation also vary and differ because of the legitimacy of any system of expressing their talents, capacities and capabilities to achieve political participation is that the government can assess the achievement of political participation in each community to recognize its legitimacy and legality of false society of true legitimacy recognized (Taghavi, 2006).

Political participation means the right to elect and be elected to political officials on the one hand and social and political positions of the other, so both elements in the definition of political participation should be noted. The definition goes on to consider two elements:

\subsubsection{Right of Choice}

With the passing of people to his social political fate of their participation in the electoral One Fields of this rule and the right to vote by this partnership is to provide them the opportunity to choose their leaders the right to vote is subject to the following conditions:

1) Importance of vote: While accepting that public participation is a sign of democracy all people without any religious discrimination, economic and social sex despite some restrictions, such as nationality, age, criminal record, the right to participate in the affairs of their country. .

2) Equality: equality of all people before the law demands that everyone be equal suffrage.

3) Vote Freedom: Vote for the people, the people should be able to vote freely in the sense that people are not forced to participate or not to participate (Hashemi, 2005).

\subsubsection{Right to Be Selected}

A democracy that is the meaning of democratic terms, suggests a leader people. Leader today means that people are somehow being in power and political rule to apply. Political governance is done today in many ways that of representation in the world today is the most famous and perhaps the most efficient (Khajeh, 2003).

Acceptance of the principle of non-guardian or, in other words the principle of the human being and the other end of the ban on the use of human beings as well as the ethical foundation for the franchise provides a solid foundation for the right to vote, or elect provides compatibility. With the explanation that the consequence of the rejection of the mandate in the field of social and political orientation. In other words, instead of another person not entitled to the same criteria rather than someone who has no right to decide. The principle of freedom requires that individuals have a mature supply to represent other people and other people do not have a moral right to prevent the exercise of authority and guardianship of their people. Prohibiting people from interfering in the sole candidate is in the person's authorities (Qari Sayed Fatemi, 2003).

Freedom of the people in choosing or electing, is an absolute and unconditional freedom rights and individual freedoms is with very few exceptions, including freedom of expression, prohibition of slavery and the prohibition of torture is absolute and unconditional - so do not be possible to elect and be elected limits on generally denied. But it should be associated with these important limitations to consider two things, first, those restrictions run contrary to the principle of quite exceptional and should be exceptional and, secondly, the restrictions must be a just and moral (Ibid).

Political freedom can be very two basic components, namely "acts of sovereignty" and "promoting political participation in society," he said. Society, including political freedom, to give people the possibility to directly or indirectly through their representatives, to exercise their sovereignty and political system in the development of society, people can work on political issues and provide peoples' participation in the political transition (Mir Ahmadi).

\subsection{Right or Duty of Political Participation}

Right is literally meant the proof and the ability of people have been told that will is therefore a key element of the determination by the rule of law is so right about the basis and essence of it can be concluded that the right of 
authority is the right of every country to protect the interests of the parties gives them.

\section{$6.3 \mathrm{GIO}$}

GIO since is the body of the judiciary and the independence and authority is relatively great, essential differences with its former inspection bodies. In this respect, such an organization should be raised from institutional goals and ideals of the revolution and guarantee accuracy country's affairs. GIO was the first institution after the revolution was about the legislation. Bill formed GIO, under the chairmanship of the Minister of Justice on Persian date 7th Esfand 1357 and was approved by the Council pursuant to Article 9 of the Act, the Office of Inspector General of the Justice Ministry and the inspection body Empire dissolved and the Justice Department were joined. GIO established before the adoption of the constitution and other state institutions under the bill.

With the adoption of the constitution of the Islamic Republic of Iran, Article 156 of supervising the implementation of laws on the Judiciary and Article 174 of the rows appointed other tasks:

"Based on the judiciary's right to monitor the proper implementation of laws current affairs and administration, an organization called "GIO" is formed by the head of the judiciary. The powers and duties of the organization determine the law. "

Act dated 19th October 1360 and GIO in December of the same year adopted an ordinance on 9th May and in the implementation of the principles, functions and powers of inspection laid it in Article 2 are as follows:

1) Continuous inspection of all ministries, departments and military and police forces and agencies, and governmental institutions and public benefit them and the offices of official documents and revolutionary institutions and organizations that all or part of its shares belong to the state capital... ;

2) Extraordinary inspection orders (judiciary) or at the request of the Commission, Parliament and ninety constitutions or at the request of the minister or the concerned executive agencies;

3) Announced the shortcomings and violations and abuse of office and financial flows, in particular the President and the ministries and revolutionary institutions and affiliated government institutions and state-owned companies, subsidiaries and units to the secretary at the ministry of Justice, the head of the judiciary;

\section{The New Constitution of Tajikistan and Its Features}

Tajikistan's constitution was put to a referendum and adopted in 1994. In this constitution, independent and democratic Republic of Tajikistan is the official language Tajik (Farsi). Freedom to use native languages according to the rules has been kept reserved for minorities. Enshrined rights and freedoms of individuals and the government is obliged to observe those rights. However, none of the parties have any right to deprive men of their independence and freedom. The seventh principle of the territorial integrity of Tajikistan's constitution and ban any kind of separatist reserved. Freedom of thoughts and activities of political parties is emphasized. The separation of powers in the Constitution is intended. International legal instruments (treaties) signed by Tajikistan, in the event of failure to comply with state laws on higher order and are binding. An economic system based on the free economic system and to ensure the activities of private individuals. Elections and public opinion in general practices, equal, direct and secret takes place by secret ballot (Mostazemy, 1995).

Tajikistan is also widespread in the constitution of individual and social freedoms for all citizens and the right be considered to life is inalienable and undeniable. In this context, the right is stressed to protection from the security people. The citizens of this Republic the right to political activity - the government is obliged to provide social and required fields for its fulfillment.

\section{The Legislative in Tajikistan}

\subsection{Combine Legislature}

Legislative Council representing the highest authority in the Republic of Tajikistan, whose members are elected for a period of 5 years.

Citizens who are 25 years old can be elected to the National Assembly. The law determines the formation and activity of the Supreme assembly (Koolaee, 1997).

\subsection{Legislative Procedures}

Before the Supreme assembly of proposed projects and measures to be discussed in parliamentary committees are excellent. Now there are seven awesome parliamentary committees that their titles are as follows:

\section{The Committee of governance structure}




\section{The Committee of rights}

3. The Committee of culture and international relations

4. The Committee of budget

5. The Committee of agriculture

6. The Committee of health, women and family affairs

7. The Committee of science and education

Each committee has a chairman and a deputy of the Supreme Council is in each. In addition to the chairman and deputy in each of the committees, according to the specialized nature of the selection committees are qualified experts.

Plans and legislation committees discuss and examine. After checking in the first planning it recommended the first meeting of the presidium of the Supreme assembly. ${ }^{3}$

Tajik law will be presented to the president for signature. If the President does not agree with the law, it is reasonable to Parliament within fifteen days of the reasons for higher returns. If the Supreme assembly legislation again with at least two-thirds approval by at least two-thirds approval again, the president-in deadline, returns the law, obliged to sign it.

\section{Tajik Women}

\subsection{Demographic and Family Structure}

At the time of the independence of the Central Asian republics of Tajikistan, in 1991, was considered one of the poorest countries in the region. Economic developments from a planned economy to free trade, the collapse of companies traditional trade and aid dependence Tajikistan Financial Moscow, has caused a dramatic fall in GDP (GNP) And a drop in national income per capita to around \$ 200 and underlying poverty and unemployment, especially among young people was intensified.

After independence, the western countries' cultural context in Central Asia were suitable for widespread propaganda, the process of converting to Islam and the Muslim culture and tradition in the tissue due to the lack of freedoms for the implementation of the religious rules in the era of the former intensified, it placed. Due to fundamental changes in the country's independence in most areas, including economic and social development, especially the attitude ideological and cultural assessment of Tajik women who constitute more than half of the population, considered an important issue in Tajikistan. Whereas the above mentioned developments have been fundamental changes women in many developing indexes to evaluate these changes and how their presence on the political scene and is important for decision-making.

\subsection{The Government's Recent Actions Regarding Women}

Recent activities of the government of Tajikistan on women held a conference entitled:

"A year after the Supreme assembly of political parties" was in the third and fourth April, 2001. The conference will contribute to the development of youth and women as part of the development program of political parties, was formed. At the meeting of political party leaders, representatives of NGOs and organizations in addition to key international policy makers about the role and participation of women and youth in political participation exchanged. The main arguments presented were:

- Efforts in promoting the activities of women in parliament.

- Establishment of volunteer organizations for women.

- Presented the activities undertaken experiences on women.

\section{Conclusion}

For implementation of civil rights, two factors are of particular importance: first laws in each state to fully and comprehensively protect their rights, secondly, the government and governmental agencies respect these rights and laws relating to the rights literally. After the correct implementation of the laws and protect the rights of citizens in a society are interconnected. If individual rights, including political rights, public law and private law we know, there is what is associated with the rights of citizens above all rooted in political rights and public rights. Political rights of citizens can be politically right to elect and be elected officials or political right positions, administrative and judicial predicted. The right to elect political participation in the political

\footnotetext{
${ }^{3}$ Interview with the President Hamid Saeed F, Consul General of Tajikistan Embassy in Tehran, dated 02.08.1988
} 
community as one of the unique features of democracy compared to other political systems. So to have a democratic character of the greatest number of people participates in the formulation of power and politics. Citizens have the right to elect their government and their agents and brokers can also find the political positions and responsibilities. Political participation in community affairs as a right that all people have and it should be a duty that is known on the shoulders of all people.

In the legal system of Iran and Tajikistan as it was before talk of citizens' political rights recognized, but with a little difference in both systems. Iran's legal system is based on religious beliefs and the beliefs of all the laws of the country enjoy a special place contrary to the legal system of Tajikistan. The implications of this at guessing people's right to choose as provided in the rules relating to legislative elections everywhere Iranian citizenship, physical and mental readiness as a condition for voting has the right to vote for and talk of a given religion. But the effect of this difference can be seen in the choice of people. In France, unlike Iran's electoral law for the election of any particular religious condition of unforeseen apart from the requirement of nationality, all people both women and men, and with the religious beliefs of political and social have the right to qualify post. As it was mentioned above the result of the religious belief and politics in this country and most European countries are considered two separate categories.

But in Iran to choose people in positions of political and social conditions there are specific religious intended to be not only officially recognized religion in the constitution are people who cannot find this post (with the exception represent recognized religious minorities are represented in parliament), but also among Iranian Muslims believe they must be proven and the supreme leader of the Islamic Republic. However, the provisions on access to social positions is considered a little easier, however, for women the same rights as men to achieve political, judicial and military careers, and in some positions are not considered such as the presidency, the army and judgment equal right to work for them have been ignored.

So comparing the two systems due to differences in the nature of these two countries can be seen that large differences can be observed. But what is clear in all international conventions relating to freedom of opinion and expression noted that the opinion of a person should not prevent his participation in social and political activities, and everyone has each and every religion of opinion and any sex who should be able to take any job that competence is the way it is. What is more important is access to jobs than to religious beliefs, scientific competence to enter that person's job.

In the field of judicial respect people's rights in Iran and Tajikistan should be noted that the changes improve the judicial system in most countries due to the pervasiveness of this issue and given that compliance with these principles one of the components of good governance and on every community forms the majority of countries, including Iran, have been conducted in recent years. As we know in this regard respecting legitimate freedoms and protecting citizens' rights, which in 1383 was adopted in respect for citizens' rights and justice. And this is a sign of attention to the rights and correct and up to date in our country.

For the strict implementation of citizenship rights as stated above with the exception of comprehensive laws that guarantee the rights of citizens, the existence of institutions that oversee law enforcement devices on the work of judicial institutions, as well as to the complaints of specific against their government is essential devices. The institutions that monitor their laws, administrative courts and the inspection and supervision are of particular importance.

Council of Tajikistan and the Guardian Council in Iran's constitution are almost similar functions in both the legal system monitoring and supervision of the election legislation and the Electoral Complaints have been the two institutions but there are some differences between the two institutions should not be taken lightly. In Iran, the Guardian Council is required to refer all decisions, but only in the fundamental laws and internal regulations in Tajikistan events this compulsion to be seen and is optional on other legislation.

But the most important difference is within the competence of election monitoring by the two institutions in the country on the whole electoral process, and approval by the Guardian Council. Selected candidates with their accreditation terms are anticipating that the normal rules of the institution of the judicial texture are more political than to review the conditions deals. But in the context of judicial candidates have introduced a constitution that most important people that have been approved by the council's constitution and the constitution just to check it pays to the legal conditions for a letter of introduction by candidates have been observed or not.

The executive is in charge of important tasks of any state in the country. Naturally, for the implementation of the many optional tasks is also given to the judiciary and its affiliated entities, as well as the institutions in any society are the most interaction with citizens. Therefore, citizens' rights may be violated in the meantime. It is here that institution to handle citizens' complaints against governmental agencies and governmental bodies 
monitor the performance of this task is necessary in most countries over the revision of the Supreme Court administrative courts administrative predict. It is the duty of the court in the country and in Tajikistan's State Council has put that country. The two agencies have similar functions and enjoy both their citizens' complaints against governmental agencies. And both are the highest authority in dealing with these complaints. And a proceeding of these two institutions is almost similar to each other. Of course, with the difference that the French State Council, part of the executive branch and the judiciary is an independent organization of the Administrative Justice Tribunal under the supervision of the Judiciary.

But the most important point is that the State Council on the functioning of the Court of Administrative Justice Advisory Council Tajik government in the area of legislative reform orders or bills by the Cabinet is approved. Although the practice to the advisory opinion is not mandatory but often used the theory and practice of government is located. In a democratic society where people's needs are constantly changing and evolving institutions that deal directly with the needs of the people and to defend the rights of their citizens can be used as a reference for a consultation on and at any time way legislative reasonable and proportional to the time the government offer. Tajikistan experienced an advisory opinion by the State Council have been successful experience, the State Council has managed its advisory jurisdiction in socioeconomic policies and administrative public service and political relationships play an important role.

Inspection machines or government agencies in most countries are dependent on the legislature or the executive or the judiciary. The institutions of our country depend on the work of governmental agencies, according to monitoring and citizen complaints or if they deem necessary the issue for further investigation to decide their devices. Inspection and monitoring the performance of governmental agencies involved in the review and monitoring for violations to the competent advisory organization and by raising the issue in the mass media and the general public about the functioning of the state apparatus over the Last Judgement. But the biggest difference is between the two institutions in their structure. GIO is an institution affiliated to the judiciary dependent on the executive branch of Tajikistan and was done under the supervision of the institution.

A noteworthy point here is that the Ombudsman has developed substantially in recent years and we are seeing the emergence of specialized Ombudsman about any organization or institution that provides a public service, and this suggests paying attention to the rights of citizens in a society that in any case the government was dissatisfied with the performance of a specialized institution to Ombudsman familiar with the functioning of that institution and to pursue raised his complaint and that marks in such a society is the rule of law.

\section{References}

Amid Zanjani, Abbas Ali. (2006). basic rights, including ancient Iran, Islamic Constitutional Movement and the Islamic Republic of Iran. Tehran, Tehran University Press.

Davidson, S., \& Castells, V. (2003) Citizenship and Immigration, translation F. T. Le, Tehran, The Center for Strategic Studies.

Gross Alpyl, H. (2003, Autumn and Winter). the universality of human rights and cultural diversity, the translation of Abraham Beygzadeh. Journal of Legal Studies, (38).

Hadavand, M. (2008). judicial supervision, conceptual analysis of major developments. publication of fundamental rights, the seventh year, Number 9 , summer.

Hashemi, M. (2005). human rights and fundamental freedoms. Tehran, publisher of printing.

Hemmati, M. (2008, Summer). Citizenship Education. Journal of basic rights, 7(9).

Khajeh, G. S. (2004). the consolidation of democratic politics, political repertoire corner of the Islamic Republic of Iran, Islamic Azad University, Issue 23 and 24 , autumn and winter.

Koolaee, E. (1997). Politics and Government in Central Asia. Tehran, Organization of Study and Compilation of Humanities Books.

McWilliams. (2000). rethink the concept of the rule of the impact of globalization on sovereignty, translation Ismail men Givi, political and economic magazine, Issue 155 and 156, p. 138.

Mir Ahmadi, M. (n.d.). Introduction to political freedom from the viewpoint of Imam Khomeini, Qom. Political Science Quarterly, (5).

Mostazemy, R. (1995). Tajikistan. Tehran, Institute for Political and International Studies.

Muharram, M. (2005, Fall and Winter). monitoring of political power from the perspective of Shiite jurisprudents. Journal of Political Science, 1 . 
Qari Sayed Fatemi, M. (2003). self-determination and the issue of election monitoring guarantee against restriction surveillance, lecturer in Humanities magazine, 7(4).

Rose, A. (2002). look at the concept and theory of globalization. national Studies, (11), 91.

Rush, M. (1998). Society and Politics, translated by M. patience. Tehran, the publisher, printing.

Schmitt, C. (2008). the political concept of law and violence (1st ed.). Tehran, Saba Cultural Publications.

Tabatabai Motameni, M. (2008). Administrative Law (5th ed.). Tehran, the publisher.

Taghavi, N. M. (2006). Effect legitimize political participation, reflection Magazine.

\section{Copyrights}

Copyright for this article is retained by the author(s), with first publication rights granted to the journal.

This is an open-access article distributed under the terms and conditions of the Creative Commons Attribution license (http://creativecommons.org/licenses/by/4.0/). 